\title{
Endomyocardial fibrosis: A restrictive cardiomyopathy in developing countries
}

\section{Fibrosis endomiocárdica: una cardiomiopatía restrictiva en países en vía de desarrollo}

\author{
Juan F. Vásquez-Rodríguez ${ }^{1 *}$, Ramón I. Medina-Mur ${ }^{1}$, Luis E. Giraldo ${ }^{1,2}$, Marietta L. Juan-Guardela ${ }^{1,2}$, \\ Julián Gelves ${ }^{1,3}$, and Claudia P. Jaimes ${ }^{1,3}$ \\ ${ }^{1}$ Cardiology Division, Fundación Cardiolnfantil IC, Faculty of Medicine and Health Sciences, Universidad El Bosque; ${ }^{2}$ School of Medicine and Health \\ Sciences, Universidad El Rosario; ${ }^{3}$ Department of Cardiovascular Imaging, Fundación Cardiolnfantil IC. Bogotá D.C., Colombia
}

\begin{abstract}
Objective: Endomyocardial fibrosis (EF) is an unusual restrictive cardiomyopathy. In Latin America there are few reports. Here, we made a description of patients diagnosed with EF in Colombia. Method: We conducted a search in the records of cardiac magnetic resonance imaging (MRI) performed in our institution between 2016-2019 looking for patients with a diagnosis of EF; sociodemographic, clinical and imaging characteristics were described. Results: Nine patients were diagnosed with EF (66.7\% female), with an average age of 69 years. Patients presented an average evolution of 2.6 years. The main reported symptom was dyspnea, followed by syncope, chest pain, and palpitations. None of them was initially suspected for EF. Regarding echocardiographic findings, predominant left ventricular involvement was identified, followed by bi-ventricular involvement. All the patients presented a restrictive filling pattern with severe left atrial dilation. In a retrospective analysis, Mocumbi criteria for diagnosis of EF were met in $100 \%$ of the patients, majority with moderate severity $(77.8 \%)$. Cardiac MRI showed biventricular systolic function and volumes preserved. Focal subendocardial late gadolinium enhancement was observed on the apex and apical thrombus was confirmed in $66 \%$ of the patients. Conclusion: $F E$ is an uncommon restrictive cardiomyopathy limited to tropical countries. Most of patients in our series presented isolated involvement of left ventricle, followed by bi-ventricular involvement, with ventricular function usually preserved.
\end{abstract}

Key words: Restrictive cardiomyopathy. Congestive heart failure. Endomyocardial fibrosis.

\section{Resumen}

Objetivo: La fibrosis endomiocárdica (FE) es una cardiomiopatía restrictiva infrecuente. En América Latina son escasos los reportes. En el presente trabajo se realiza una descripción de una serie de pacientes diagnosticados de FE en Colombia. Método: Realizamos una búsqueda en los registros de imágenes de resonancia magnética (RM) cardiaca realizadas en nuestra institución entre 2016 y 2019 en busca de pacientes con diagnóstico de FE. Se describieron sus características sociodemográficas, clínicas y de imagen. Resultados: Nueve pacientes fueron diagnosticados de FE (el $66.7 \%$ mujeres), con una edad promedio de 69 años. Los pacientes presentaron un promedio de 2.6 años de evolución. El principal síntoma referido fue disnea, seguido de síncope, dolor torácico y palpitaciones. En ninguno de ellos se sospechó FE como diagnós-

\section{Correspondence:}

*Juan F. Vásquez-Rodríguez

E-mail: juanfevasquez8@gmail.com
Date of reception: 11-04-2020

Date of acceptance: 24-06-2020

DOI: 10.24875/ACME.M21000196
Available online: 19-07-2021

Arch Cardiol Mex (Eng). 2021;91(2):165-170 www.archivoscardiologia.com license (http://creativecommons.org/licenses/by-nc-nd/4.0/). 
tico inicial. En cuanto a los hallazgos ecocardiográficos, se identificó compromiso predominante del ventrículo izquierdo, seguido de compromiso biventricular. Todos los pacientes presentaron patrón de llenado restrictivo con dilatación auricular izquierda severa. En el análisis retrospectivo se cumplieron los criterios de Mocumbi para el diagnóstico de FE en el 100\% de los pacientes con gravedad moderada (77.8\%). Las imágenes de RM mostraron función sistólica biventricular y volúmenes preservados. Se observó depósito focal de gadolinio subendocárdico a nivel apical y se confirmó la presencia de trombo en el $66 \%$ de los casos. Conclusión: La FE es una cardiomiopatía restrictiva infrecuente circunscrita a países tropicales. La mayoría de los pacientes en nuestra serie presentaron compromiso aislado del ventrículo izquierdo, seguido de compromiso biventricular, con función ventricular usualmente preservada.

Palabras clave: Cardiomiopatía restrictiva. Falla cardiaca congestiva. Fibrosis endomiocárdica.

\section{Introduction}

Endomyocardial fibrosis (EMF) is a rare restrictive cardiomyopathy considered a tropical disease associated with "low-income" countries. When a Medline search with the search term "endomyocardial fibrosis" is performed, a limited source of information is displayed between 1946 and 2020, with an average of 46 articles per year. In 1948, Davis described the first case in Uganda ${ }^{1}$, and currently, 10-12 million people are estimated to be affected worldwide ${ }^{2}$. Age at presentation has a bimodal behavior, with a first peak at age 10 and a second peak at 30 years $^{3}$. The countries with the highest prevalence of the disease are located on the equatorial line, with Nigeria being the most affected country.

Reports are scarce in Latin America ${ }^{2}$, and existing evidence comes from Brazil and Colombia; in the latter country there are three case reports ${ }^{4-6}$ with similar characteristics to those described in patients from the African continent.

The purpose of this study is to describe a series of cases diagnosed with EMF in a cardiovascular referral center in Bogota, Colombia, describing their sociodemographic, clinical and multimodal cardiovascular imaging diagnostic characteristics.

\section{Method}

We carried out a search in the records of cardiac magnetic resonance imaging (MRI) exams carried out in our institution between 2016 and 2019 looking for patients with an EMF diagnosis. The patients should also have echocardiography studies carried out at the same institution.

Echocardiography assessments were performed with Phillips iE33 (Koninklijke Philips N.V.), Phillips EPIQ7 (Koninklijke Philips N.V.) and GE VividE9 (General Electric Company) devices. Cardiac MRI images were obtained with a Phillips Ingenia 1.5 T equipment (Koninklijke Philips N.V.).

Sociodemographic, clinical and imaging characteristics were described.

\section{Results}

Nine patients with EMF diagnosis were identified. General characteristics are described in table 1; 66.7\% were females and average age was 69 years. Average time between diagnosis and data collection cutoff date was 2.6 years, with no mortality recorded in this period. The most commonly referred symptom was dyspnea, followed by syncope, chest pain and palpitations. In patients with syncope $(5,55.6 \%)$, etiology was classified as follows: of cardiac origin in two due to the presence of unsteady ventricular tachycardia and sinus dysfunction diagnosed by findings on 24-hour Holter heart rhythm monitoring associated with symptoms; neurally-mediated or vasovagal in two patients with positive tilt-table test with mixed response; and orthostatic in one patient with possible autonomic dysfunction induced by diabetes and high doses of antihypertensive drugs.

All patients had at least one 12-lead electrocardiography tracing. Six of the nine patients were in sinus rhythm and the remaining three were in atrial fibrillation rhythm with controlled ventricular response. Of the six patients in sinus rhythm, all had some intraventricular conduction disorder, in five of them it was characterized as nonspecific disorder and in one as complete left bundle branch block. All patients had diffuse repolarization disorders related to the previously described conduction disorders.

In none of them was EMF suspected as initial clinical diagnosis. Diagnostic suspicion was raised after echocardiographic evaluation, without a definitive diagnosis in none of the cases being established by this method. 
Table 1. Population general characteristics

\begin{tabular}{|c|c|}
\hline & Total: $\mathbf{9 ,}$ n (\%) \\
\hline Females & $6(66.7)$ \\
\hline Age (years) & $69 \pm 8$ \\
\hline $\begin{array}{l}\text { Symptoms } \\
\text { Chest pain } \\
\text { Dyspnea } \\
\text { Palpitations } \\
\text { Syncope } \\
\text { Limb edema }\end{array}$ & $\begin{array}{l}3(33.3) \\
6(66.7) \\
3(33.3) \\
5(55.6) \\
1(11.1)\end{array}$ \\
\hline $\begin{array}{l}\text { Initial diagnosis } \\
\text { CHF } \\
\text { HCM } \\
\text { Ischemic heart disease } \\
\text { Apical thrombus } \\
\text { Chest pain on evaluation }\end{array}$ & $\begin{array}{l}3(33.3) \\
2(22.2) \\
2(22.2) \\
1(11.1) \\
1(11.1)\end{array}$ \\
\hline $\begin{array}{l}\text { Echocardiographic findings } \\
\text { Biventricular compromise } \\
\text { Left ventricular compromise } \\
\text { Right ventricular compromise }\end{array}$ & $\begin{array}{c}2(22.2) \\
7(77.8) \\
0(0)\end{array}$ \\
\hline $\operatorname{LVEF}(\%)$ & $45 \pm 11$ \\
\hline LVEDV (mL) & $58 \pm 15$ \\
\hline Indexed LA volume $\left(\mathrm{mL} / \mathrm{m}^{2}\right)$ & $60 \pm 23$ \\
\hline Restrictive diastolic pattern & $9(100)$ \\
\hline $\begin{array}{l}\text { Mocumbi diagnostic criteria } \\
\text { Yes } \\
\text { Mild } \\
\text { Moderate } \\
\text { Severe }\end{array}$ & $\begin{array}{l}9(100) \\
1(11.1) \\
7(77.8) \\
1(11.1)\end{array}$ \\
\hline $\begin{array}{l}\text { Cardiac MRI findings } \\
\text { LVEF }(\%) \\
\text { RVEF }(\%) \\
\text { Indexed LVEDV }\left(\mathrm{mL} / \mathrm{m}^{2}\right) \\
\text { Indexed RVEDV }\left(\mathrm{mL} / \mathrm{m}^{2}\right)\end{array}$ & $\begin{array}{c}60 \pm 4 \\
55 \pm 8.0 \\
59 \pm 25 \\
82 \pm 47\end{array}$ \\
\hline $\begin{array}{l}\text { Apical thrombus (cardiac MRI-confirmed) } \\
\text { Yes }\end{array}$ & $6(66.6)$ \\
\hline
\end{tabular}

CHF: congestive heart failure; HCM: hypertrophic cardiomyopathy; LA: left atrium; LVEDV: left ventricular end-diastolic volume; LVEF: left ventricular ejection fraction; MRI: magnetic resonance imaging; RVEDV: right ventricular end-diastolic volume; RVEF: right ventricular ejection fraction.

The echocardiogram identified predominant left ventricular involvement, followed by biventricular involvement, with mild left ventricular systolic dysfunction. All patients had a restrictive filling pattern with severe left atrial dilation. Main diagnoses were hypertrophic cardiomyopathy or apical thrombus (or both). When a retrospective analysis was performed, $100 \%$ of patients met the Mocumbi criteria (Table 2) for EMF diagnosis, which was of moderate grade in $77.8 \%$.

Among the parameters evaluated by echocardiographic diagnostic criteria, the most common were, in order: $>2$ mm thick endomyocardial plaques (9/9), right or left ventricular apex obliteration (9/9, predominantly left ventricular apex, in eight patients), restrictive flow pattern across mitral or tricuspid valves (9/9), atrial dilation with normal-sized ventricles (4/9), anterior mitral valve diffuse thickening (2/9) and atrioventricular valves dysfunction due to adhesion of the valve apparatus to the ventricular wall $(1 / 9$, with presence of moderate mitral regurgitation).

Cardiac MRI characterization was carried out in all patients, with biventricular systolic function and volumes being normal. In the late enhancement sequence, involvement was exclusive to the sub-endocardium at apical segments; in two patients, there was extension to left ventricular middle segments. Apical thrombus was identified in $66 \%$ of patients.

The described patients continued on clinical follow-up by the cardiology department. At hospital discharge, $88.8 \%$ received a beta-blocker, $77.7 \%$ an angiotensin-converting enzyme (ACE) inhibitor or an angiotensin II receptor blocker (ARB-II), 22.2\% furosemide and only $10 \%$ spironolactone or hydrochlorothiazide.

After sociodemographic, clinical and imaging data were reviewed, establishing any causal relationship for the disease was not possible.

\section{Discussion}

Endomyocardial fibrosis is an unusual condition, particularly limited to countries defined as "tropical" or of low-income ${ }^{2}$, frequently underdiagnosed and with poor described information, which makes its identification and treatment complicated.

This condition does not have a clearly established presentation age. Symptoms are referred to be usually late in the course of the disease. Some authors point at early ages, with a peak during childhood and a second peak in adult life ${ }^{7}$. However, in our study, ages ranged from the fifth to the seventh decades of life.

It has been speculated that EMF may have three phases: one of acute inflammation, usually asymptomatic and rarely detected, in which is probable for eosinophilia to be identified $^{9}$; there is another indeterminate or transitional phase; and, finally, a chronic phase, in which signs and symptoms of heart failure become evident. Confirming this behavior in clinical trials has not been possible ${ }^{2}$.

The disease is characterized by a typically restrictive pattern (Fig. 1) secondary to a process of fibrosis that affects the sub-endocardial surface, typically of apical 
Table 2. EMF echocardiographic diagnostic criteria - Mocumbi criteria

\begin{tabular}{|l|c|}
\hline Criterion & Points \\
\hline Major criteria & 2 \\
\hline Endomyocardial plaques $>2$ mm in thickness & 3 \\
Thin $<1$ mm) endomyocardial patches affecting more than one ventricular wall & 4 \\
Obliteration of the right or left ventricular apex & 4 \\
\hline Thrombi or spontaneous contrast without severe ventricular dysfunction & 4 \\
\hline Right ventricular apex retraction & $1-4+$ \\
\hline Atrioventricular valve dysfunction of due to adhesion of the valvular apparatus to the ventricular wall & \\
\hline Minor criteria & 1 \\
\hline Thin endocardial patches localized to one ventricular wall & 2 \\
\hline Restrictive flow pattern across mitral or tricuspid valves & 2 \\
\hline Pulmonary valve diastolic opening & 1 \\
Diffuse thickening of the anterior mitral leaflet & 2 \\
\hline Enlarged atrium with normal-size ventricle & 1 \\
M-movement of the interventricular septum and flat posterior wall* & 1 \\
\hline Enhanced density of the moderator or other intraventricular bands &
\end{tabular}

Definite diagnosis is made with 2 major criteria or 1 major criterion and 2 minor criteria.

Score < 8: mild; 8 - 15: moderate; and > 15: severe.

AV: Atrioventricular.

*M-movement of the interventricular septum refers to a pattern of movement observed on M-mode echocardiography that is thought to be due to obliteration of restriction of the left ventricular apex combined with mitral regurgitation.

+ Classify according to regurgitation severity.

Adapted from Mocumbi et al. $2008^{8}$.

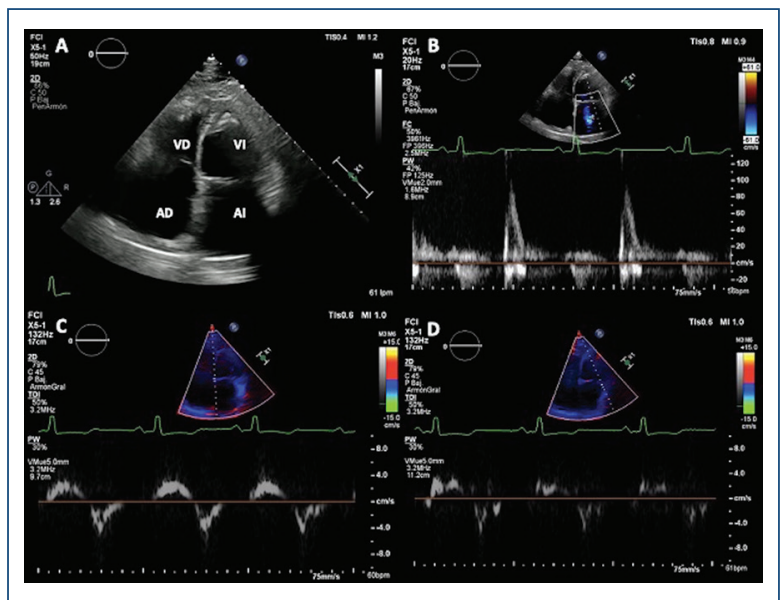

Figure 1. EMF findings on transthoracic echocardiogram. A: 4-chamber apical projection with apex obliteration and severe biatrial dilation. B: Mitral valve pulsed Doppler with $1.2 \mathrm{~m} / \mathrm{s}$ E-wave, < $160 \mathrm{~ms}$ deceleration and E/A ratio > 2 . C: Mitral annulus septal tissue Doppler, e' wave of $0.4 \mathrm{~m} / \mathrm{s}$. D: Mitral annulus lateral tissue Doppler, e' wave $0.4 \mathrm{~m} / \mathrm{s}$. The findings are consistent with restrictive diastolic dysfunction. AD: right atrium; Al: left atrium; VD: right ventricle; VI: left ventricle.

localization (Fig. 2). This condition was present in all our patients.

Previous studies have described that involvement is biventricular in half of cases $(50 \%)$, followed by exclusive involvement of the left ventricle $(40 \%)$ and

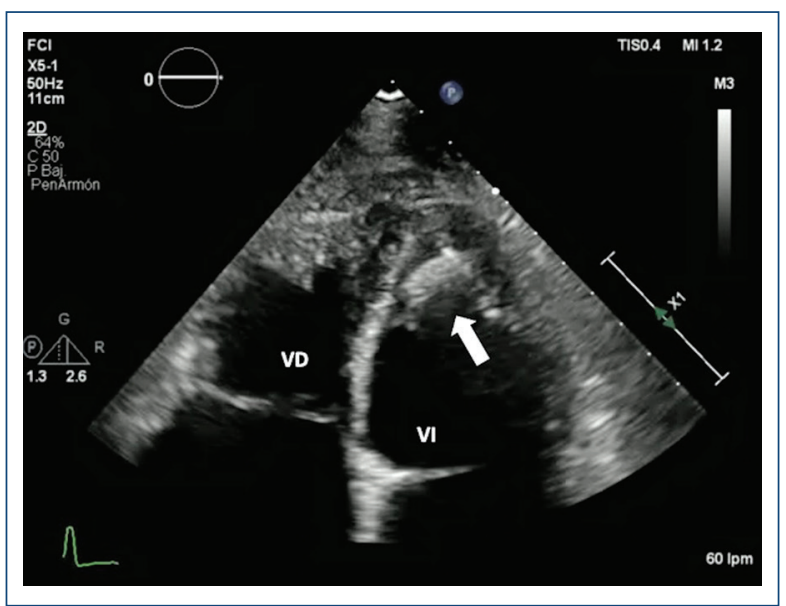

Figure 2. Transthoracic echocardiogram. 4-chamber apical projection with zoom for ventricles, with apical obliteration and an image on apex suggestive of apical thrombus (arrow). VD: right ventricle; VI: left ventricle.

exclusive involvement of the right ventricle $(10 \%)^{10}$. In patients with left ventricular compromise, fibrosis may spread to the middle segments and mitral valve posterior leaflet, respecting the anterior leaflet and left ventricular outflow tract ${ }^{11}$. In the patients herein described, isolated left ventricular involvement was the main presentation pattern, and there were only two cases of biventricular compromise and none with exclusive right ventricular involvement. 


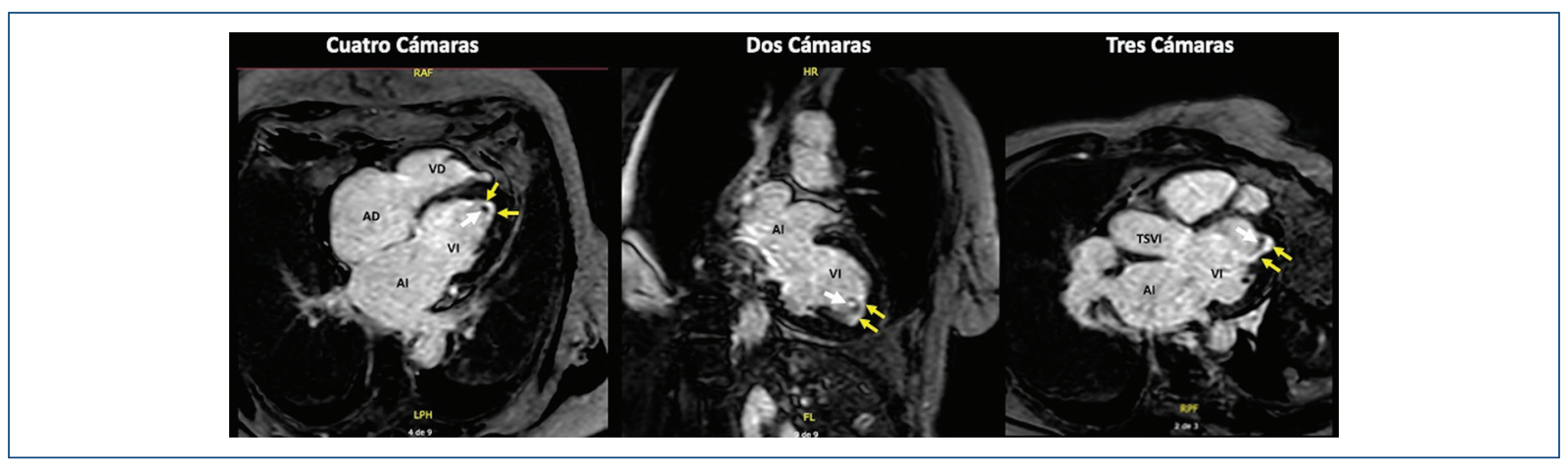

Figure 3. Cardiac magnetic resonance imaging, late enhancement sequences. Focal gadolinium deposition areas of sub-endocardial distribution (arrows) representing the compromise by endomyocardial fibrosis are observed. Immediately before the enhancement areas, an ovoid hypointense image is observed, which corresponds to an apical thrombus. Cuatro Cámaras: Four-chamber; Dos Cámaras: Two-chamber; Tres Cámaras: Three-chamber; AD: right atrium; Al: left atrium; TSVI: left ventricular outflow tract; VD: right ventricle; VI: left ventricle.

Patients with right ventricular involvement characteristically have jugular distension, hepatomegaly, ascites and lower limb edema ${ }^{11}$. In some patients, severe ascites has been identified without other signs of right heart failure, suggesting the possibility of compromise due to fibrosis and peritoneal inflammation ${ }^{2}$. We did not identify ascites in our patients.

Theories with regard to etiology are diverse. In our description, establishing any causal relationship was not possible. Some infectious agents, especially parasitic, such as schistosomes, filariae and plasmodia, have been linked to the development of the disease, by favoring the presence of eosinophilia and a possible disproportionate inflammatory reaction in the endocardium. Dietary factors, such as consumption of cassava (Manihot esculenta crantz), a tuber containing linamarin and that releases hydrogen cyanide in the gastrointestinal tract, have also been proposed as another possible etiology by altering the biology of cardiomyocytes. Animal models have shown myocardial tissue intracellular vacuolization and interstitial fibrosis with the consumption of cassava ${ }^{3}$. Finally, a possible genetic susceptibility, so far not very well supported, has been proposed.

Diagnosis of the disease is frequently overlooked given that it is confused with other conditions such as hypertrophic cardiomyopathy, cardiac sarcoidosis, amyloidosis and apical thrombi ${ }^{12}$. In our series, initial diagnoses were, in order: congestive heart failure, hypertrophic cardiomyopathy, ischemic heart disease and apical thrombus.

Transthoracic echocardiogram is a useful tool when the disease is suspected. In 2008, a study was carried out to evaluate the prevalence of the disease in a rural population of Mozambique using transthoracic echocardiography as diagnostic method; from this study, the criteria for EMF echocardiographic diagnosis, also known as Mocumbi criteria, were derived (Table 2) ${ }^{8}$. One-hundred percent of the population analyzed in our study met the diagnostic criteria, with the most common findings being the presence of endomyocardial plaques that can obliterate the ventricular apex, associated with restrictive pattern and atrioventricular valves compromise with some degree of dysfunction. The diagnostic criteria also allow disease severity to be staged, which was moderate in most our cases.

Cardiac MRI is another imaging technique that is highly useful for EMF diagnosis, since it allows to identify areas of sub-endocardial fibrosis distribution (Fig. 3) and to reclassify ventricular chambers size and function, as it occurred in this series, as well as apical thrombi identification, which have been described in up to $40 \%$ of the population ${ }^{13}$. In our series, apical thrombi were identified in $66 \%$ of patients (Figs. 3 and 4 ).

As for EMF treatment and prognosis, some series report a survival no longer than 2 years at advanced stages of the disease ${ }^{14}$. It was higher in the patients of our series, who have achieved more than 2 years of evolution since diagnosis, without deaths so far having being recorded.

Treatment is based on the guidelines for chronic heart failure standard care. For the patients herein described, the use of beta-blockers, ACEI or ARB-II was higher than $75 \%$. Definitive therapy is heart transplantation. 


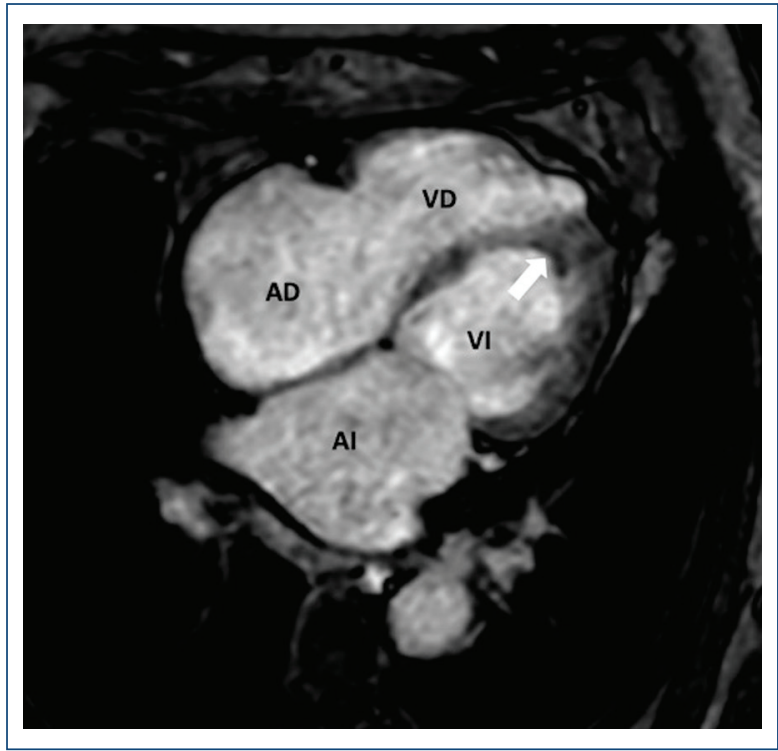

Figure 4. Four-chamber cardiac magnetic resonance imaging. PSIR TFE sequence, hypointense image (arrow) corresponding to an apical thrombus is observed. $A D$ : right atrium; Al: left atrium; VD: right ventricle; VI: left ventricle.

\section{Conclusion}

EMF is a rare type of restrictive heart disease, diagnosed in so-called "tropical" countries, with exclusive left ventricular or biventricular compromise, variable prognosis and poorly established etiology. Treatment is based on neuro-humoral blockage, and heart transplantation is the definitive therapy.

\section{Funding}

This research did not receive any specific grant from funding agencies in the public, commercial or non-profit sectors.

\section{Conflicts of interest}

The authors declare that they have no conflicts of interest.

\section{Ethical disclosures}

Protection of human and animal subjects. The authors declare that no experiments have been performed on humans or animals for this research.

Confidentiality of data. The authors declare that they have followed the protocols of their work center on the publication of patient data.

Right to privacy and informed consent. The authors declare that no patient data appear in this article.

\section{References}

1. Connor DH, Somers K, Hutt MSR, Manion WC, D'Arbela PG. Endomyocardial fibrosis in Uganda (Davies' disease). 1. An epidemiologic, clinical, and pathologic study. Am Heart J. 1967;74:687-709.

2. Beaton A, Mocumbi AO. Diagnosis and management of endomyocardial fibrosis. Cardiol Clin. 2017;35:87-98.

3. Grimaldi A, Mocumbi AO, Freers J, Lachaud M, Mirabel M, Ferreira B, Narayanan K, et al. Tropical Endomyocardial Fibrosis: Natural History, Challenges, and Perspectives. Circulation. 2016;133(24):2503-15.

4. Rodríguez-González MJ, Torres AM, Echeverría LE. Fibrosis endomiocárdica. Rev Colomb Cardiol. 2017;24:407.e1-5.

5. Villamil-Munévar A, Barbosa C, Ternera-Barrios A, Luis J, Olaya A. Fibrosis endomiocárdica. Rev. Colomb. Cardiol. 2017;24(1):59.

6. Uenishi EK. Reporte de un caso de endomiocardiofibrosis en Colombia Falta revista. 2014;21:414-8.

7. Bukhman G, Ziegler J, Parry E. Endomyocardial fibrosis: still a mystery after 60 years. PLoS Negl Trop Dis. 2008:2:1-7.

8. Mocumbi AO, Ferreira MB, Sidi D, Yacoub MH. A population study of endomyocardial fibrosis in a rural area of Mozambique. N Engl J Med. 2008;359:43-9.

9. Andy JJ, Bishara FF, Soyinka OO. Relation of severe eosinophilia and microfilariasis to chronic African endomyocardial fibrosis. Br Heart J. 1981:45:672-80.

10. Bhatti K, Lopez-Mattei J. Endomyocardial fibrosis. StatPearls. 2020. (Consultado el 26 de enero de 2020.) Disponible en: http://www.ncbi.nlm. nih.gov/pubmed/30020665

11. Marangou J, Beaton A, Aliku TO, Nunes MCP, Kangaharan N, ReményiB. Echocardiography in indigenous populations and resource poor settings. Hear Lung Circ. 2019:28:1427-35

12. Dato I. How to recognize endomyocardial fibrosis? J Cardiovasc Med. 2015;16:547-51

13. Gulati GS, Sharma AK, Paliwal S, Seth $S$, Ramakrishnan S, Jagia $P$, et al. Cardiac magnetic resonance in tropical endomyocardial fibrosis. J Cardiovasc Magn Reson. 2011;13(S1):P270.

14. Bhatti K, Bandlamudi M, Lopez-Mattei J. Endomyocardial Fibrosis. [Updated 2020 Aug 12]. In: StatPearls [Internet]. Treasure Island (FL): StatPearls Publishing; 2021 Jan-. Available from: https://www.ncbi.nlm.nih.gov/books/NBK513293/. 